\title{
Impact of Full IFRS, Accounting Standards for SMES and Company Demographics on Firms' Return on Asset and Return on Equity using Panel Data Regression
}

\author{
Rodiel C. Ferrer
}

\begin{abstract}
Due to globalization, markets are becoming more interconnected as the companies are engaged in doing cross-border offerings. Currently, competitions are intensified because Domestic organizations discover themselves competing with each nearby opposite numbers and worldwide companies. But one component that hinders SMEs is the need for reliable and similar monetary data. According to Abarca (2014), adoption of a high-quality and consistent set of accounting requirements is critical so as for the businesses to remain competitive in ASEAN member states. This paper ambitions to answer the query, what modified into the extent of the impact of compliance with full IFRS and IFRS for SMEs on profitability of agencies belong to real property enterprise? This paper moreover sought to decide whether there may be a sizeable distinction among the groups' compliance with the overall PFRS and the PFRS for SMEs and to determine whether or now not there is a massive distinction among the companies' financial normal overall performance earlier than and after the adoption of the PFRS for SMEs.Paired $T$-test have become employed in case you need to determine whether there is a big distinction between the agencies' compliance with the entire PFRS and the PFRS for SMEs and to decide whether or not there may be a big difference some of the groups' monetary performance earlier than and after the adoption of the PFRS for SMEs. Using STATA, the great appropriate version for every economic ratio on the subject of degree of compliance emerge as determined on. First, take a look at parm command became used to find out which most of the Least Squares Dummy Variable Regression Modes (LSDV1, LSDV2, LSDV3) underneath the Fixed Effects Model is the ideal version. Afterwards, Hausman Fixed Random Test changed into used to pick out out which is more suitable amongst Fixed Effects Model and Random Effects Model. If Fixed Effects Model modified into the more appropriate one, the Wald's test turn out to be used to determine the best version among Fixed Effects Model and Ordinary Least Squares Model. On the alternative hand, if Random Effects Model became the more suitable one, the Breusch and Pagan Lagrangian Multiplier Test for Random Effect have become used to decide the satisfactory version amongst Random Effects Model and Ordinary Least Squares. Moreover, if Ordinary Least Squares became the splendid model, it is going to be in addition tested to check for heteroscedasticity and multicollinearity. White's test became used to check for heterescedasticity and Variance Inflation Factor have become used to test if multicollinearity is gift. The results display that the adoption of PFRS for SMEs stepped forward the compliance of Philippine real property SMEs. However, no vast alternate became said inside the financial average performance of those companies (as measured with the resource of cross back on assets and go back on equity). This was further supported by the results of the panel regression. This means that despite having a relatively
\end{abstract}

easier time in complying with the required accounting standards, this did not translate to having lower significantly costs related to compliance. It was also noted that firm characteristics, namely, firm age and firm size, are generally not correlated with the firm's profitability.

Keywords: Full IFR, IFRS For SMEs, Disclosure Index and Profitability.

\section{INTRODUCTION}

It became in 2001 while the IASB has the authorization to create suited accounting necessities for proprietor-managed, personal, non-publicly accountable entities a good way to meet their financial reporting desires (Bohusova and Blaskova, 2011). In developing accounting requirements for SMEs, its fundamental objective is to provide a framework which may be with out issues implemented to generate information that is applicable, dependable, and of excessive excellent (Veronica and Ionel, 2010).

IASB published its first talk paper entitled: Preliminary Views on Accounting Standards for Small and Medium-sized Entities that addresses important troubles closing 2004 (Neag, Masca and Pascan,2009). It grow to be located by means of the usage of the launched of the Exposure Draft of the IFRS for SMEs in 2007 that originated from the total IFRS with suitable modifications based totally at the desires of users of SMEs economic statements and value-gain worries. Throughout the improvement procedure, IASB achieved severa issue checks with a view to analyze the relevance of the accounting favored in which the checking out application have become completed to 116 small entities where each of the entity has a complete of up to 50 personnel in 20 amazing countries (Pacter, 2009). As a end result, IASB end up capable of find out issues together with the use of honest fee approach as the precept technique of comparing the final of each economic yr because of market fluctuation and the want to simplify the records presented (Pacter, 2009). After a five-12 months improvement system with rigorous consultation of SMEs worldwide, IFRS for SMEs became published via IASB on July nine, 2009. IASB objectives to define a unified set of exceptional, comprehensible and enforceable accounting requirements, to drop financial 


\section{IMPACT OF FULL IFRS, ACCOUNTING STANDARS FOR SMES AND COMPANY DEMOGRAPHICS ON FIRMS' RETURN ON ASSET AND RETURN ON EQUITY USING PANEL DATA REGRESSIO}

burden, to allow clean switch to full IFRS for those SMEs which will determine to transport to IFRS or the ones so that you can collect a duty to make accounting facts public, and to pay attention on enjoyable the dreams of clients of economic statements of SMEs (Mullerova, Pasekova and Kubickova, 2010). Furthermore, IASB believes that IFRS for SMEs will offer superior comparison for users of financial statements, beautify the general self guarantee in monetary statements of SMEs, reduce substantial costs related with preserving requirements on a countrywide foundation, and enable to smooth transition to finish IFRS at developing groups which can be getting ready to cross into public capital markets in reaction to robust global requirements of each developed and rising economies (Mullerova, Pasekova and Kubickova, 2010).

The IFRS for SMEs is a separate and unbiased from entire IFRS; therefore, it's miles available for any jurisdiction to decide which entities ought to use the standard. Since it is created primarily based on IFRS basis, some of the ideas in complete IFRS for reputation and measurement of assets, liabilities, earnings and prices were simplified and a few topics now not applicable to SMEs were overlooked. There had been 5 key changes made through IASB that allows you to cope with the goals of SMEs for a simpler, more practical and powerful monetary reporting. First, earnings consistent with proportion, meantime economic reporting, segment reporting, insurance and particular accounting for property held on the market are overlooked due to the fact it's far appeared to be irrelevant to SMEs. Secondly, times in which the full IFRS gives preference on accounting guidelines, the IFRS for SMEs only prescribed the less difficult alternative. IFRS for SMEs does no longer offer any alternatives on the subsequent: monetary gadgets - to be had available on the market, held to maturity and honest fee opportunity; revaluation model for property, plant and device and intangible belongings; proportionate consolidation for investments in joint ventures; and various alternatives for government affords. Thirdly, reputation and size of assets, liabilities, earnings and expenses are simplified as compared to the entire IFRS. Fourthly, some disclosures were neglected. In complete IFRS, there are 3,000 required disclosures while in IFRS for SMEs, there are handiest round 3 hundred required disclosures. The motives for the good sized discount of required disclosures are the following: (i) disclosure necessities have already been substituted with the simplifications inside the IFRS for SMEs; (ii) some of the disclosure necessities are not relevant as to the needs of SME financial statement customers; and (iii) those omissions did no longer skip the price-advantage factors along with disclosures directed at making funding picks in public markets. Lastly, the drafting of the usual changed into simplified for less hard knowledge, thereby disposing of needless provisions within the system (Epstein and Jermakowicz, 2009).

Due to globalization, markets are getting extra interconnected because the groups are engaged in doing flow-border offerings. Currently, competitions are intensified due to the fact home agencies discover themselves competing with each nearby opposite numbers and worldwide agencies. But one element that hinders SMEs is the want for dependable and comparable monetary statistics. According to
Abarca (2014), adoption of a high-quality and steady set of accounting requirements is critical so as for the corporations to live competitive in ASEAN member states. This paper pursuits to reply the question, what turned into the extent of the effect of compliance with complete IFRS and IFRS for SMEs on profitability of organizations belong to actual property organisation? This paper additionally sought to determine whether there's a tremendous difference among the organizations' compliance with the whole PFRS and the PFRS for SMEs and to determine whether or now not there may be a tremendous distinction among the corporations' economic overall overall performance earlier than and after the adoption of the PFRS for SMEs.

\section{REVIEW OF RELATED LITERATURE}

\section{Small and Medium-Sized Entities (SMEs)}

Across international locations, the technical definition of SMEs varies. Typically, SMEs definition is based on employment, belongings or combination of the two. Based on International Accounting Standards Board (IASB), SMEs is described as entities that to do now not have public obligation and positioned up general-purpose economic statements for outside users. An entity has public responsibility if it documents or it is within the approach of submitting its economic statements with a securities commission or extraordinary regulatory organisation for the motive of issuing any elegance of instruments in a public market; or it holds belongings in a fiduciary functionality for a huge organization of outdoor as one in every of its primary commercial enterprise. However, entities protecting property in a fiduciary ability for reasons incidental to a primary company are not considered to be publicly responsible and can therefore use the IFRS for SMEs. On the alternative hand, within the Philippines, there are operational definitions of SMEs consistent with National Statistics Office. First, SME is defined primarily based mostly on employment, wherein small company comprise of 10 to ninety nine personnel at the same time as medium corporation include of 100-199 employees. It is the maximum typically used definition in the united states. Second, SME is defined based mostly on property wherein small agency has general property of P3 million to P15 million even as P15 million to P100 million common belongings for medium corporation. As the Philippines Financial Reporting Standards Council followed IFRS for SMEs, Philippine Securities and Exchange Commission (SEC) covered extra quantitative criteria within the definition of SME. It mandated on its SRC Rule sixty eight that it'd be classified as an SME if it has overall assets of among P3 million and P350 million or basic liabilities of among P3 million and P250 million.

Generally, SMEs play an important position within the financial system. In the Philippines, SMEs have an vital characteristic within the monetary device specially in the place of employment. SMEs are contributing considerable 
numbers to the kingdom's monetary upswing as they contribute $35 \%$ to america's gross domestic product (GDP) and rent about $70 \%$ of the overall Philippine work pressure. (Dulay, 2014). Statistics on Micro, Small and Medium-sized Enterprises (MSMEs) as of 2014 within the Philippines were said through manner of the Department of Trade and Industry as follows:

Table 1

Total Establishment Per Size of Enterprise as of 2014

\begin{tabular}{|l|l|l|}
\hline Size of Enterprises & Number of Establishment & Percentage \\
\hline Micro & 851,756 & $89.94 \%$ \\
\hline Small & 87,283 & $9.22 \%$ \\
\hline Medium & 3,886 & $0.41 \%$ \\
\hline Large & 4,063 & $0.43 \%$ \\
\hline Total & 946,989 & $100 \%$ \\
\hline
\end{tabular}

[1] Source: From MSME Statistics by Department of Trade and Industry, 2014.

It can be seen in Table 1, 99.57\% of total business enterprises are MSMEs where $9.63 \%$ are comprised of SMEs. Based on the preliminary result data on 2014 Annual Survey of Philippine Business and Industry (ASPBI) and reported by DTI, the top five most numbered industries of MSMEs business establishments in 2014 are $46.47 \%$ $(437,205)$ from Wholesale and Retail Trade; Repair of Motor Vehicles and Motorcycle industries; $13.52 \%$ (127,518) from Accommodation and Food Services; followed by $12.48 \%$ $(117,642)$ from Manufacturing; 6.43\% $(60,668)$ from Other Service Industries; and 4.15\% $(39,107)$ from Information and Communication.

It is mentioned above that one significant contribution of SMEs in economy is employment. DTI (2014) reported a $7,789,257$ total employment in $2014,32.34 \%$ were generated by SMEs. The top five industries sector that has most number of employments for MSMEs in 2014 are Wholesale and Retail, Repair of Motor Vehicles and Motorcycles (35.46\%); Manufacturing (16.07\%); Accommodation and Food Service Activities (13.87\%); Education (5.62\%); and Administrative and Support Service Activities (4.87\%).

\section{Adoption of PFRS for SMEs}

Last October 2009, Philippine Financial Reporting Standards Council (PFRSC) and the SEC adopted IFRS for SMEs effective January 1, 2010, however, SEC permitted qualified SMEs to have an early adoption of PFRS for SMEs on December 31, 2009. In line with this, SEC issued a public notice with regard to the definition of SMEs with the following criteria (Punongbayan and Araullo, 2010): (i) with Total belongings among P3 million and P350 million or widespread liabilities amongst P3 million and P250 million; (ii) aren't required to report economic statements below Securities Regulation Code (SRC) Rule 68.1 for unlisted and personal entities; (iii) are not inside the method of submitting financial statements for the cause of issuing any beauty of gadgets in a public marketplace; (iv) are not holders of secondary licenses issued with the aid of manner of a regulatory organisation such as banks, investments houses, finance businesses, securities dealer/dealers, mutual price range and pre-want agencies and (v) are not public utilities.

PFRS for SMES is compulsory for all economic statements for annual intervals, besides for an entity based on the subsequent standards (Punongbayan and Araullo, 2010):

i. It is a subsidiary of a discern organization reporting underneath the overall PFRS;

ii. It is a subsidiary of a overseas determine agency at the manner to be transferring in the direction of IFRS pursuant to the overseas u. S . A .'s published convergence plan;

iii. It is a subsidiary of a foreign determine organisation that has been making use of the requirements for a non-publicly responsible entity for close by reporting purposes, and is considering shifting to full PFRS in preference to the PFRS for SMEs so one can align its regulations with the predicted waft to finish IFRS via using its foreign parent organisation pursuant to its usa's published convergence plan;

iv. It has a brief-term projections that show that it'll breach the quantitative thresholds set within the criteria for an SMEs, and the breach is anticipated to be large and persevering with because of its lengthy-term impact at the agency's asset or legal responsibility length;

$\mathrm{v}$. It is a part of a hard and fast, either as a full-size joint venture or an partner this is reporting underneath the whole PFRS;

vi. It is a branch administrative center of a distant places agency reporting underneath the full IFRS;

vii. It has concrete plans to conduct an initial public imparting within the next two (2) years;

viii. It has a subsidiary that is mandate to record below the total PFRS; and

ix. It has been getting prepared monetary declaration the use of entire PFRS and has decided to liquidate its belongings.

SMEs are lifeblood of Philippine's economic device as they stimulate financial hobby, generate employment, spark off innovation, heighten competition and make a contribution in massive part to the u . S .'s development. However, Philippine SMEs preserve to face vital problems and worrying situations as regards to their lifestyles, improvement and competitiveness.

Based on a file furnished by Rafaelita Aldaba (2014), Gearing Up SMEs for Association of South East Asian Nations Economic Community 2015, MSMEs function a vital motive force for growth but it has now not been lively enough to propel the financial system because of constraints such as lack of get entry to to finance, lack of get right of entry to to generation \& abilities, and availability of inputs and deliver chain troubles. With regard to economic issues, in a take a look at also accomplished by using manner of Rafaelita Aldaba (2012) entitled Small and Medium Enterprises' Access to Finance: Philippines, banks revealed that they flip down financial requests due to corporations' bad credit score facts, restricted proper collateral, inadequate monetary statements and business agency plans. Banks are reluctant to lend cash to SMEs because of their favored aversion to handling a bigger quantity of small accounts. Also, banks mentioned that the dearth of credit score statistics has deterred them from lending to SMEs. In addition, banks are worried approximately the bankability of 


\section{IMPACT OF FULL IFRS, ACCOUNTING STANDARS FOR SMES AND COMPANY DEMOGRAPHICS ON FIRMS' RETURN ON ASSET AND RETURN ON EQUITY USING PANEL DATA REGRESSIO}

SMEs and high dangers concerned in lending SMEs for the purpose that many SMEs have restrained control and economic functionality. As a give up result, banks have continued to impose voluminous and stringent necessities. Based at the examine moreover, so that you can have get proper of entry to to finance, survey results shows that a company have to has high income boom, immoderate profitability rate and whose proprietors generally have a tendency to have better net certainly well worth.

Yason (2014) explains that SMEs have a commonplace and on the spot want for an good enough accounting infrastructure however of getting splendid merchandise, offerings and agency techniques. An adequate accounting shape will offer SMEs with timely and correct monetary statements as a manner to address the supply of economic facts this is right and beneficial for capability creditors or capitalists. This economic information is essential for capability lenders since it serves as an tool for evaluating the proper monetary fitness and condition of an SME.

\section{Cost and Benefits of PFRS for SMEs Adoption}

Adoption of IFRS for SMEs offers upward thrust to wonderful advantages. With the attention of every the requirements of superior and growing international locations, IASB attests that the requirements will facilitate greater contrast; improve fundamental take delivery of as real with inside the monetary statements of SMEs; decrease critical charges connected with compliance to requirements; and allow smooth transition to full IFRS for developing entities which can be getting ready to sign up for the capital markets (Chyzhevska, Mullerova, Pasekova and Strouhal (2010).

In the paper entitled: Actual factors regarding the IFRS for SMEsopinions debates, and destiny developmentsby Masca, Neag and Pascan (2009), states that IFRS for SMEs is anticipated to provide comparison of financial statements while improving the general self guarantee of customers inside the money owed of SMEs, accordingly, it will help reduce the price of retaining requirements on a country extensive basis. SMEs with pass-border sports, branches and subsidiaries will benefit the most from IFRS for SMEs as they may experience simplification in making their economic critiques due to the fact that they will be able to use one modern-day and accounting framework in all international locations. Furthermore, IFRS for SMEs will now not most effective deliver benefits to SMEs itself however moreover to country wide substantial setters and capital companies or investor as it gives comparison and credibility within the monetary statements through way of enhancing the organisation's transparency in financial reporting. For country wide popular setters will no longer need to deliver their personal set of requirements and maintain them updated in an effort to in the end result to a fee discount at countrywide degree. On the opposite hand, for capital vendors and investors, adoption of IFRS for SMEs will useful resource them in making higher selection in an effort to bring about a extra green functioning of capital markets and lower rate of capital for the whole economy (Raju, n.D.).

Adoption of IFRS for SMEs also has its costs. In a magazine article entitled Less is More written by Shearer and Sleigh-Johnson (2009), states that moving to a new standard inevitably entails cost and effort. One cost is that the language will be unfamiliar to some, that it will take some time for its users to get used to it. In addition, there will be a change in the accounts-generation system used by SMEs. As these changes occur, it will require extensive project management, as it will shell out cost from companies, which do not have the necessary resources.

Moreover, complexity of the same vintage for small companies is one of the prices to recollect in adopting IFRS for SMEs as it will reason more burden for corporations, specifically to those companies which can be working in most effective one u.S. That have no need for bypass-border comparison. Opponents argue that adopting IFRS for SMEs isn't suitable for internal manipulate. There might be a need for companies and their accountants to transform their inner procedures, train the staff on the brand new accounting structures and produce statements of comparative statistics (Stokdyk, 2010). Based on the test of Strouhal, Pasekova and Mullerova (2010), one of the prices and drawbacks in compulsory adoption of IFRS for SMEs included greater education costs for accountants and personnel to boom the records of new accounting desired but this extra fee might also additionally have an extended-term benefits for corporations. However, a few combatants consider that adoption of IFRS for SMEs will quit result to an growth in disclosure necessities that may cause a competitive drawback (Stokdyk, 2010).

Considering the blessings and costs of adopting the IFRS for SMEs, its blessings outweigh its expenses. With the severa traumatic situations SMEs are experiencing with their economic reporting, SMEs want to now keep in mind to deliver beneficial and dependable financial facts because of the enhancing economic machine and globalization. According to Yason (2014), SMEs ought to get prepared to discovered out their percent of the blessings inside the appreciably expected and competitive and useful business corporation environment via making equipped timely and ok economic reviews that allows you to translate into organized access to credit score rating for SMEs.

\section{Foreign Studies}

Compliance of Small and Medium-sized Entities to the IFRS for SMEs

A comparative assessment end up finished via Buys and Schutte (2011) to assess modern disclosure practices thru South African SMEs closer to the IFRS for SMEs' illustrative financial statements that focuses on content material fabric cloth assessment. Based on the researchers literature assessment, it positioned that compliance with IFRS is inconsistent among nations and it seems that glaringly IFRS is extra best to global places with politically and legally robust environments. Based from a sample of 100 SMEs in amazing industries in South Africa, the researchers positioned out that there had been extra disclosures for declaration of financial function money owed than profits announcement debts with one-of-a-type formats used in the 
presentation of financial statements. The small quantity of companies that provided revaluations found out that honest fee reporting is not common in SMEs confirms it. Results confirmed that best sixty one $\%$ of sample supplied a announcement of cash flows on the identical time as disclosure in the declaration of changes in fairness changed into restrained to profits and losses. Lastly, effects confirmed that IFRS for SMEs; illustrative financial statements is probably followed without an entire lot hassle that is why the researchers encouraged that the IFRS for SMEs need to come to be the desired accounting framework for SMEs in South Africa.

Impact of Compliance to IFRS for SMEs to the Overall Firm Performance of SMEs

In a study finished by way of manner of Palka and Svitakova (2011) entitled Impact of IFRS for SMEs Adoption on Performance of Czech Companies, researchers used a comparative take a look at primarily based simply on the impact of IFRS for SMEs and Czech Accounting Standards on the firm's performance that focuses on the shareholder perspective by concentrating on profitability. The researchers used the DuPont as its financial measure, which concentrates on the net margin, asset turnover and financial leverage. Results shows that ROE is decreased by $0.74 \%$ and 7 other ratios decreased while the other 12 ratios increased. Results also show that the average deviation is below $1.5 \%$, thus, researchers concluded that there is no significant difference between compliance to Czech Accounting Standards and IFRS for SMEs.

Relationship Between Financial Performance and Financial Characteristics

Symeou (2010) conducted a study, entitled The Effects of Economy Size on Firm Performance: Evidence from the Telecommunication Sector, results showed a positive relationship between firm performance and economic size, which is based on the number of employees of the firms. Also, Dogan (2013) conducted a study to examine the effect of firm size on firm's profitability. For firm's size indicator, the researcher used total assets, total sales, number of employees, liquidity ratio, leverage ratio and age of the firm. On the other hand, the researcher used Return on Assets as an indicator for firm's profitability. Using multiple regression and correlation methods, the researcher concluded that there is a positive relationship between firm size and firm performance. In contrast, based on the study conducted by Pervan and Visic (2012), results showed that firm size has a weak positive impact on firm profitability. The researchers explained that the weak relationship is explained by the separation of ownership from the management that shifted manager's focus from maximization of profit to maximization of managerial utility. On the other hand, the positive impact is due to the market power of larger firms that able to charge higher prices that enable them to earn larger profits.

\section{Real Estate Activities}

The Philippine Standard Industrial Classification (PSIC) under Section L classifies the Real Estate Activities zone. Real Estate sports are divided into : 1real estate sports with very own or leased property and 2real property sports on a fee or settlement foundation. Real property activities with very own or rent assets includes searching for, promoting, renting and operation of self-owned or leased actual estate collectively with 1apartment homes and dwellings; 2non-residential homes, which includes exhibition halls, self-garage facilities, department shops and buying facilities; and 3land. On the opposite hand, actual property activities on a rate or settlement foundation includes lactivities or actual property entrepreneurs and agents; 2intermediation in looking for, promoting and renting of real property on a rate or settlement foundation; 3management of real belongings on a charge or contract basis; 4appraisal services for actual belongings; and 5activities of actual property escrow shops. (NSCB, 2009).

Based on the 2013 Annual Survey of Philippine Business and Industry by using the Philippine Statistics Authority (2016), there are four,814 establishments engaged in Real Estate Activities in which four,198 (87.2\%) institutions are engaged in actual estate activities with very very own or leased property whilst 616 (12.Eight\%) institutions are engaged in actual property sports on a fee or agreement foundation.

In 2013, seventy one, 453 personnel have been hired inside the place. Almost all $(99,6 \%)$ were paid personnel and the rest have been running proprietors or unpaid people. Ninety.Nine\% $(64,959)$ were hired people beneath actual belongings sports activities with private or leased assets whilst the final $9.1 \%(6,494)$ have been employed people beneath actual estate sports on a fee or settlement foundation. A wellknown of P20.5B in 2013 modified into paid for total reimbursement to personnel, with an average annual reimbursement in step with worker of P287,500. Workers in actual estate sports on a charge or settlement basis acquired higher common annual compensation (P373,600) than those in actual belongings sports with very very own or leased assets $(\mathrm{P} 278,900)$

The area generated a whole earnings of $\mathrm{P} 423.3 \mathrm{~B}$ and incurred widespread charges of P274.7B in 2013. Real estate sports with very very own or leased property contributed $97.6 \%$ of general profits and $96.7 \%$ general prices at the identical time as 2. Four $\%$ of widespread profits and 3 . Three\% for actual estate sports activities on a price or contract basis. Furthermore, value added generated thru the sector totaled to P201.6B in 2013 in which $98.1 \%$ in actual property sports with very own or least property at the same time as 1. Nine $\%$ in real property sports on a rate or agreement basis.

\section{SME and Real Estate Activities}

Across international locations, the technical definition of SMEs varies. Typically, SMEs definition is based totally totally on employment, property or aggregate of the two. In the Philippines, there are two operation definitions of SMEs. First, SME is defined primarily based on employment, in which small enterprise consist of of 10 to ninety nine employees at the same time as medium enterprise agency include of 100-199 personnel. It is the most typically used

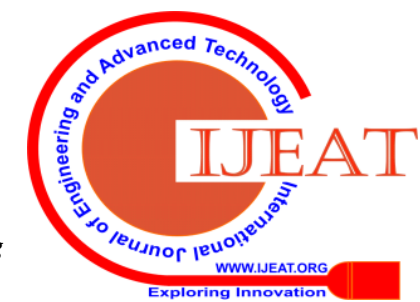




\section{IMPACT OF FULL IFRS, ACCOUNTING STANDARS FOR SMES AND COMPANY DEMOGRAPHICS ON FIRMS' RETURN ON ASSET AND RETURN ON EQUITY USING PANEL DATA REGRESSIO}

definition in the us of a. Second, SME is defined based totally on assets in which small company has average assets of $\mathrm{P} 3$ million to P15 million while P15 million to P100 million total assets for medium agency. Furthermore, International Accounting Standards Board (IASB) defines SMEs as entities that to do no longer have public accountability and submit good sized-motive economic statements for outside customers. An entity has public duty if 1it files or it's far inside the method of submitting its economic statements with a securities commission or distinctive regulatory business enterprise for the cause of issuing any beauty of devices in a public marketplace; or 2it holds assets in a fiduciary capability for a extensive organization of outside as taken into consideration one in all its primary commercial enterprise. However, entities preserving belongings in a fiduciary capacity for motives incidental to a number one business enterprise aren't taken into consideration to be publicly responsible and may therefore use the IFRS for SMEs. Since IASB did now not mention any size criteria for SMEs, the Philippine Securities and Exchange Commission SRC Rule 68 set a length criterion for SMEs thru having general belongings of among P3 million and P350 million or overall liabilities of amongst P3 million and P250 million.

\section{METHODOLOGY \& RESULTS}

\section{Sampling Design}

A pattern of 30 agencies for Real Estate Activities enterprise become used. The pattern blanketed in this paper surpassed the SME criteria of SEC that lit has standard assets among P3 million and P350 million or total liabilities among P3 million and P250 million; 2it isn't always required to file monetary statements underneath SRC Rule 68.1 for unlisted and personal entities; 3is no longer in the system of submitting financial statements for the motive of issuing any elegance of devices in a public market; 4it isn't always a holder of secondary licenses issued by way of the use of a regulatory organization; and ${ }^{5}$ it is not a public utility.

\section{Research Procedures}

In conducting this study, determination of the sample was the first step. The sample should be in the list of small and medium-sized entities in Real Estate Activities industry in the Philippines. Furthermore, the sample entities must have used full PFRS for the year 2007 to 2009 and PFRS for SMEs for the year 2010 to 2012. Since small and medium-sized entities are not publicly listed, data collection was conducted through the use of SEC i-View online facility.

After data gathering, second step is calculation of disclosure index to determine the degree of compliance for each sample entities. It will be measured based on the information available in the financial statements and notes of the financial statements. Furthermore, disclosure checklists were employed in order to systematically identify whether the sample entities complied with the full PFRS and PFRS for SMEs. Afterwards, the financial ratios listed in the model were computed from the values in the financial statements particularly in the Statement of Financial Position and Income Statement. In addition, the size of the firm and years of existence were part of the quantitative data to be tested and analyzed as a measurement for firm size and firm age

respectively for the correlation test.

Paired T-test was employed in order to determine whether there is a significant difference between the firms' compliance with the full PFRS and the PFRS for SMEs and to determine whether there is a significant difference between the firms' financial performance before and after the adoption of the PFRS for SMEs. Also, to aid the paired t-test in checking for any significant changes in disclosure index and financial ratios from year 2007 to 2012, trend analysis was used to identify any pattern in both the degrees of compliance and the financial ratios.

Numerous tests were employed to determine whether there is a significant effect of the degree of compliance with the full PFRS for periods 2007 to 2009 and PFRS for SMEs for periods 2010 to 2012 on the firms' performance. Using STATA, the best appropriate model for each financial ratio in relation to degree of compliance was selected. First, test parm command was used to identify which among the Least Squares Dummy Variable Regression Modes (LSDV1, LSDV2, LSDV3) under the Fixed Effects Model is the appropriate model. Afterwards, Hausman Fixed Random Test was used to identify which is more appropriate between Fixed Effects Model and Random Effects Model. If Fixed Effects Model was the more appropriate one, the Wald's test was used to determine the best model between Fixed Effects Model and Ordinary Least Squares Model. On the other hand, if Random Effects Model was the more appropriate one, the Breusch and Pagan Lagrangian Multiplier Test for Random Effect was used to determine the best model between Random Effects Model and Ordinary Least Squares. Moreover, if Ordinary Least Squares was the best model, it will be further tested to check for heteroscedasticity and multicollinearity. White's test was used to check for heterescedasticity and Variance Inflation Factor was used to check if multicollinearity is present. The researcher used the Stata software in order to conduct the different tests needed for the research.

\section{Operational Framework}

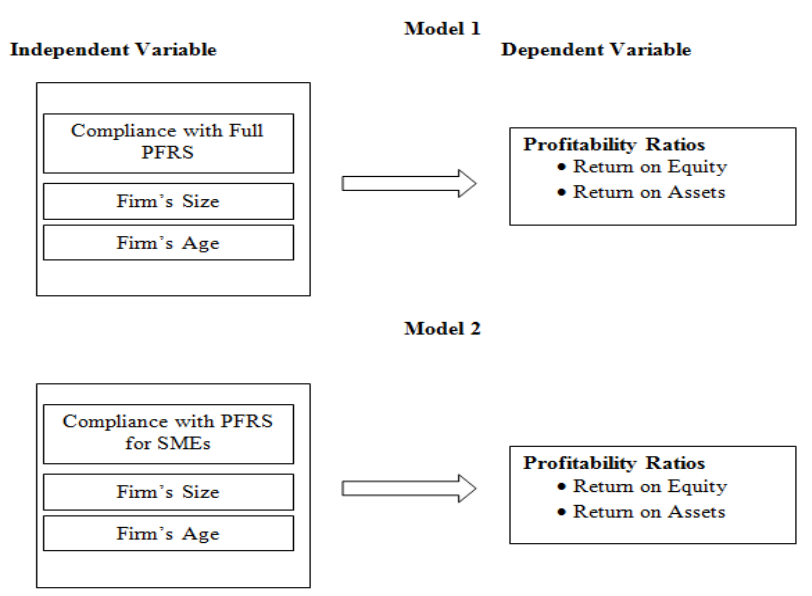




\section{Presentation of Findings, Analysis and Implication}

\section{Disclosure Index}

To establish the level of compliance to the standards, the disclosure indices of the thirty companies in Real Estate Activities Sector. For comparability, for years 2007-2009, 2009 Philippine Financial Reporting Standards (PFRS) Disclosure and Content Checklist by Isla Lipana \& Co. was used while for years 2010-2012, PFRS for SMEs Disclosure and Content Checklist by Isla Lipana and Co. These disclosure checklists were used as a reference in calculating the disclosure indices. Furthermore, trend analysis and paired t-test were conducted to determine if there was a significant change in the degree of compliance of small and medium-sized entities under the said industries before and after the implementation of the PFRS for SMEs.

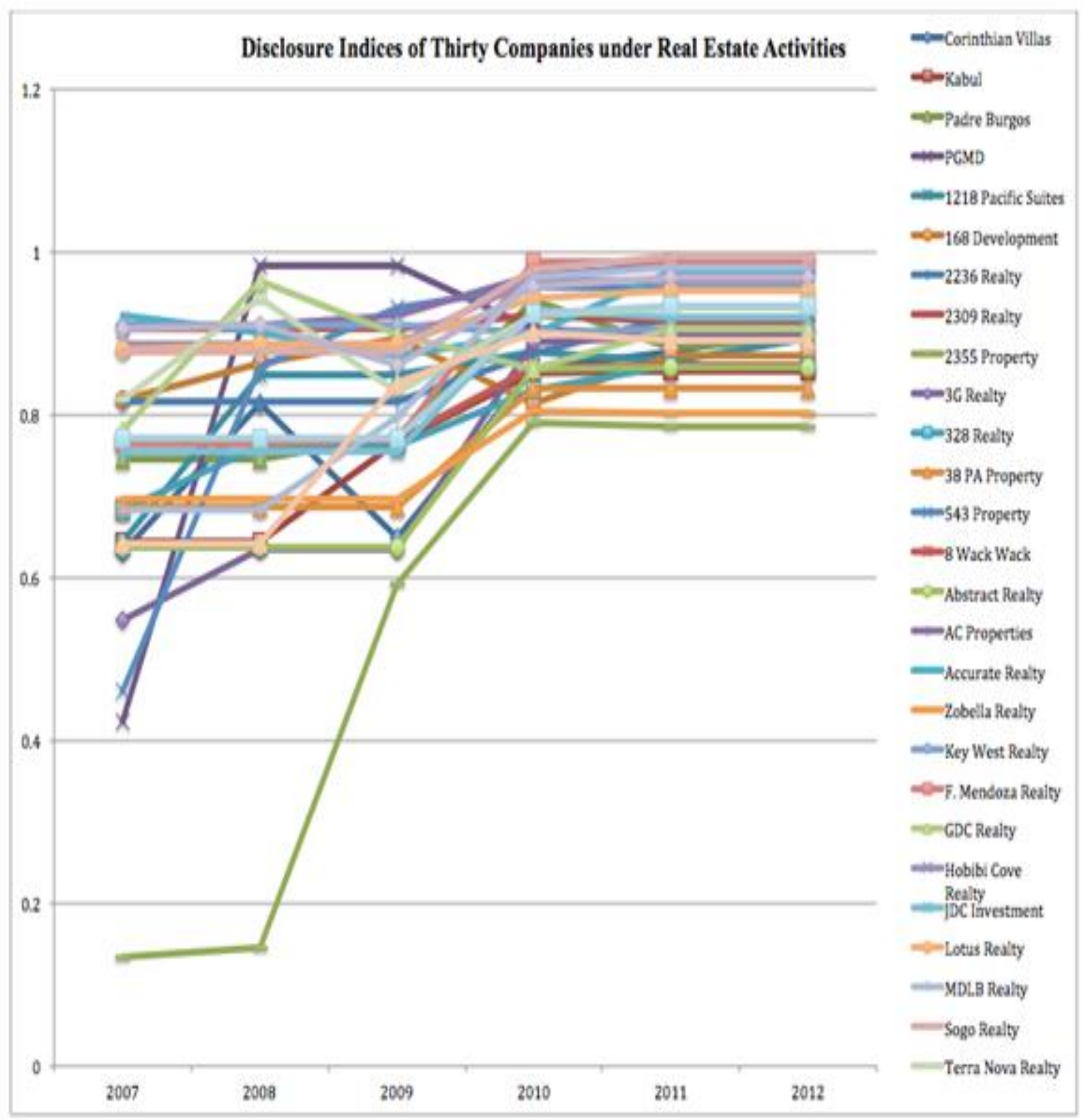

Figure 1: Disclosure Indices of Companies in Real Estate Activities

Figure 1 illustrates the trend of the disclosure indices of the companies under Real Estate Activities. Almost all companies showed an increasing trend in their disclosure indices as they adopted the PFRS for SMEs. It can be seen particularly in the upward curve between 2009 and 2010, which serves as the period of transition from the full PFRS to the PFRS for SMEs. Thus, it implies that companies have been more compliant with the PFRS for SMEs as compared when they were implementing the full PFRS. Furthermore, the detailed numbers on figure _ is presented on Table which lists down the disclosure indices of each company under Real Estate Activities. Table _ present more clearly the difference between the change in the level of compliance with the full PFRS (2007-2009) and PFRS for SMEs (2010-2012). In Real Estate Activities, it has an average disclosure compliance of $77 \%$ when full PFRS was implemented while an average disclosure compliance of $91 \%$ when PFRS for SMEs was implemented.

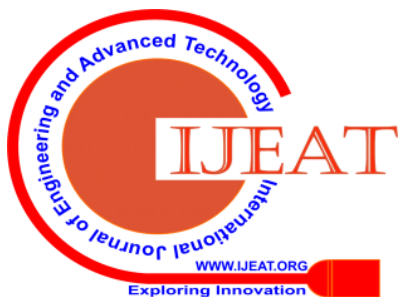


IMPACT OF FULL IFRS, ACCOUNTING STANDARS FOR SMES AND COMPANY DEMOGRAPHICS ON FIRMS' RETURN ON ASSET AND RETURN ON EQUITY USING PANEL DATA REGRESSIO

Table 1

Disclosure Indices of Each Company for years 2007-2012

\begin{tabular}{|c|c|c|c|c|c|c|}
\hline Company & 2007 & 2008 & 2009 & 2010 & 2011 & 2012 \\
\hline Corinthian Villas & 0.630769231 & 0.813492063 & 0.648962149 & 0.855567766 & 0.876556777 & 0.905606431 \\
\hline Kabul & 0.643282313 & 0.643282313 & 0.766071429 & 0.851740328 & 0.853413692 & 0.853413692 \\
\hline Padre Burgos & 0.744598765 & 0.744598765 & 0.773888889 & 0.939705882 & 0.881109944 & 0.893014706 \\
\hline PGMD & 0.423611111 & 0.981891348 & 0.981891348 & 0.904700855 & 0.896037296 & 0.896037296 \\
\hline $\begin{array}{l}1218 \text { Pacific } \\
\text { Suites }\end{array}$ & 0.643042672 & 0.849165121 & 0.849165121 & 0.876775148 & 0.86650641 & 0.894284188 \\
\hline 168 Development & 0.8171875 & 0.86287478 & 0.893738977 & 0.813748833 & 0.872574484 & 0.872574484 \\
\hline 2236 Realty & 0.816145833 & 0.816145833 & 0.816145833 & 0.874532313 & 0.91917517 & 0.919368132 \\
\hline 2309 Realty & 0.905753968 & 0.905753968 & 0.905753968 & 0.922008547 & 0.915509259 & 0.915509259 \\
\hline 2355 Property & 0.133848134 & 0.145431145 & 0.592905405 & 0.789831349 & 0.785876623 & 0.785876623 \\
\hline 3G Realty & 0.547008547 & 0.634615385 & 0.634615385 & 0.889957265 & 0.895104895 & 0.895104895 \\
\hline 328 Realty & 0.682745826 & 0.761595547 & 0.761595547 & 0.830395299 & 0.860431235 & 0.860431235 \\
\hline 38 PA Property & 0.686177249 & 0.686177249 & 0.686177249 & 0.831623932 & 0.831468531 & 0.831468531 \\
\hline 543 Property & 0.45952381 & 0.858451073 & 0.932058899 & 0.958333333 & 0.954545455 & 0.954545455 \\
\hline 8 Wack Wack & 0.767857143 & 0.767857143 & 0.767857143 & 0.858638331 & 0.861168831 & 0.861168831 \\
\hline Abstract Realty & 0.636150235 & 0.636150235 & 0.636150235 & 0.856682207 & 0.858804832 & 0.858804832 \\
\hline AC Properties & 0.909774436 & 0.909774436 & 0.921052632 & 0.970177045 & 0.982617383 & 0.982617383 \\
\hline Accurate Realty & 0.921052632 & 0.900837258 & 0.871565934 & 0.898148148 & 0.976767677 & 0.976767677 \\
\hline Zobella Realty & 0.69664903 & 0.69664903 & 0.69664903 & 0.805079643 & 0.802511125 & 0.802511125 \\
\hline Key West Realty & 0.908928571 & 0.908928571 & 0.910714286 & 0.900065746 & 0.905626781 & 0.905626781 \\
\hline $\begin{array}{l}\text { F. Mendoza } \\
\text { Realty }\end{array}$ & 0.763157895 & 0.763157895 & 0.768796992 & 0.98838141 & 0.987325175 & 0.987325175 \\
\hline GDC Realty & 0.780590717 & 0.963532248 & 0.897528632 & 0.856725146 & 0.90430622 & 0.90430622 \\
\hline $\begin{array}{c}\text { Hobibi Cove } \\
\text { Realty }\end{array}$ & 0.886785714 & 0.886785714 & 0.886785714 & 0.966025641 & 0.963194444 & 0.963194444 \\
\hline JDC Investment & 0.754545455 & 0.754545455 & 0.754545455 & 0.928021978 & 0.92002442 & 0.92002442 \\
\hline Lotus Realty & 0.878858025 & 0.886574074 & 0.886574074 & 0.943869165 & 0.953080484 & 0.953080484 \\
\hline MDLB Realty & 0.68297456 & 0.68297456 & 0.797089041 & 0.969284188 & 0.981643357 & 0.981643357 \\
\hline Sogo Realty & 0.87654321 & 0.87654321 & 0.87654321 & 0.977416174 & 0.995833333 & 0.995833333 \\
\hline $\begin{array}{c}\text { Terra Nova } \\
\text { Realty }\end{array}$ & 0.818295735 & 0.942105263 & 0.828014842 & 0.922409188 & 0.930506993 & 0.930506993 \\
\hline Fullerton Realty & 0.90625 & 0.909375 & 0.861111111 & 0.957692308 & 0.968055556 & 0.968055556 \\
\hline IUG Realty & 0.77047619 & 0.77047619 & 0.77047619 & 0.924223856 & 0.932486631 & 0.932486631 \\
\hline Leyba Realty & 0.641025641 & 0.641025641 & 0.838827839 & 0.899839744 & 0.890734266 & 0.890734266 \\
\hline
\end{tabular}

Paired T-test on Disclosure Index

To determine if there is a significant difference in the degrees of compliance of the companies between the implementation of the full PFRS and the PFRS for SMEs. During the implementation of the full PFRS for years 2007-2009, degree of compliance has a mean of 0.77 while 0.88 during the implementation of the PFRS for SMEs. Comparing the degree of compliance before and after the implementation of PFRS for SMEs, degree of compliance had a mean difference of 0.11 . This positive mean difference implies that there was an increase in the degrees of compliance of the companies and they become more compliant to the PFRS for SMEs. In addition, this test generated a p-value less than 0.05 at $95 \%$ level of confidence. Therefore, it can be concluded that there is a significant difference between the degrees of compliance with the full PFRS and the PFRS for SMEs.
Table 2

Paired T-Test on Degree of Compliance between Full PFRS and PFRS for SMEs

\begin{tabular}{|c|c|c|c|c|c|c|}
\hline Variable & obs & Mean & Std. Err. & Std. Dev. & [95\% Conf & Interval] \\
\hline pfrsfo x & 30 & .8798818 & 0126759 & .0694289 & .8539566 & 905807 \\
\hline fullpf $\sim x$ & & .7731334 & .0222807 & .1220364 & .7275643 & .8187026 \\
\hline diff & 30 & .1067484 & 0197029 & 1079174 & .0664514 & 1470454 \\
\hline \multirow{2}{*}{\multicolumn{7}{|c|}{$\begin{array}{rlrl}\text { mean }(\text { diff })=\text { mean (pfrsforsmesindex }- \text { fullpfrsindex }) & t=5.4179 \\
\text { mean }(\text { diff })=0 & \text { degrees of freedom }= & 29\end{array}$}} \\
\hline & & & & & & \\
\hline \multicolumn{2}{|c|}{ Ha: $\operatorname{mean}($ diff $)<0$} & \multicolumn{3}{|c|}{ Ha: mean(diff) $!=0$} & \multicolumn{2}{|c|}{$\begin{array}{l}\text { Ha: mean(diff) }>0 \\
\operatorname{Pr}(T>t)=0.0000\end{array}$} \\
\hline
\end{tabular}


To further verify this significant increase in compliance from full PFRS to PFRS for SMEs, the degrees of compliance to selected standards were analyzed.

Table 3

Paired T-test: Section 3,4,5,6 and 8 vs. PAS 1 or Presentation of Financial Statements

\begin{tabular}{r|rrrrrr}
\hline Variable & obs & Mean & std. Err. & Std. Dev. & [95\% Conf. Interval] \\
\hline sec345 n & 30 & .9453092 & .0088033 & .0482178 & .9273044 & .9633141 \\
pas1mean & 30 & .8351188 & .0168116 & .0920807 & .8007353 & .8695023 \\
\hline diff & 30 & .1101905 & .0127919 & .0700644 & .084028 & .1363529 \\
\hline
\end{tabular}

mean $($ diff $)=\operatorname{mean}(\sec 34568$ mean - pasimean $) \quad t=8.6141$

Ho: mean (diff) $=0 \quad$ degrees of freedom $=29$

Ha: mean(diff) $<0 \quad$ Ha: mean(diff) $!=0 \quad$ Ha: mean (diff) $>0$

$\operatorname{Pr}(T<t)=1.0000 \quad \operatorname{Pr}(|T|>|t|)=0.0000 \quad \operatorname{Pr}(T>t)=0.0000$

Table 3presents the paired t-test results with regard to the companies' compliance with the required disclosures in the Presentation of Financial Statements. In PFRS for SMEs, there are five standards for the presentation of financial statements while in full PFRS; it is covered with only one standard, which is PAS 1. Section 3 is about the Financial Statement Presentation, Section 4 is about the Statement of Financial Position, Section 5 is about Statement of Comprehensive Income and Income Statement, Section 6 is about Statement of Changes in Equity and Statement of Income and Retained Earnings; and Section 8 covers the Notes to the Financial Statements.

It can be seen that during the implementation of full PFRS, the average degree of compliance was 0.84 . Furthermore, it can be noticed that companies become more compliant upon the transition to PFRS for SMEs as their degree of compliance was increased to 0.95 . This resulted to a positive mean difference of 0.11 . The commonly not complied with disclosure requirements of PAS 1 of full PFRS and Sections 3, 4, 5, 6 and 8 of the PFRS for SMEs is presented in Table _. With a p-value of 0.00 , it can be concluded that there is a significant difference in the degree of compliance between Section 3, 4, 5, 6 and 8 .

Table 4

Common Non-compliance on Presentation of Financial Statements: Section 3, 4, 5, 6 and 8 vs. PAS

1

- Disclosure in the statement of financial position or statement of changes in equity or in the notes for each class of share capital: the rights, preferences and restrictions attaching to that class, including restrictions on the distribution of dividends and the repayment of capital.

- Disclosure in the summary of significant accounting policies or other notes, of the judgments that management has made in the process of applying the entity's accounting policies that have the most significant effect on the amounts recognized the financial statements.

- Disclosure of information about the assumptions made about the future and other major sources of estimation uncertainty at the end of the reporting period, that have a significant risk of resulting in a material adjustment to the carrying amounts of assets and liabilities within the next fiscal year.

- Disclosure of information that enables users of its financial statements to evaluate the entity's objectives, policies and processes for managing capital.

Table 5

Paired T-test: Section 7 vs. PAS 7 or Statement of Cash Flows

\begin{tabular}{|c|c|c|c|c|c|c|}
\hline riable & Obs & Mean & Std. Err. & Std. Dev. & {$[95 \%$ Cor } & Inter \\
\hline & & & & & & \\
\hline & & .9640212 & & & & \\
\hline diff & 30 & .0322751 & . 02328998. & .1275632 & 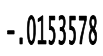 & \\
\hline \multicolumn{4}{|c|}{$\begin{aligned} \text { mean }(\text { diff }) & =\text { mean (sec7mean }- \text { pas7mean) } \\
\text { Ho: mean (diff) } & =0\end{aligned}$} & \multicolumn{3}{|c|}{$\begin{aligned} t & =1,3858 \\
\text { degrees of freedom } & =29\end{aligned}$} \\
\hline $\begin{array}{l}a_{1} \\
r(T\end{array}$ & & & $|>| t$ & & & \\
\hline
\end{tabular}

Table 5 shows the paired t-test results with regard to the companies' compliance with the required disclosures in the Statement of Cash Flows. It can be seen that for the periods 2007-2009, as companies complies with full PFRS, particularly PAS 7, the average compliance was 0.96 . On the other hand, for periods 2010-2012, as companies transitioned to PFRS for SMEs, the average compliance was increased to 0.99 . This resulted to a 0.32 mean difference. This positive mean difference reflects that companies had a higher degree of compliance with the implementation of PFRS for SMEs as they started to be more compliant by correcting their errors in not disclosing particular provision of the said standard. However, despite of the increase in disclosure index, paired t-tests generated a p-value of 0.1765 , which can be concluded that there is no significant difference in the degree of compliance between Section 7 and PAS 7.

According to PAS 7 (2010), classification of cash flows by activity is meant to provide "information that allows users to assess the impact of those activities on the financial 


\section{IMPACT OF FULL IFRS, ACCOUNTING STANDARS FOR SMES AND COMPANY DEMOGRAPHICS ON FIRMS' RETURN ON ASSET AND RETURN ON EQUITY USING PANEL DATA REGRESSIO}

position of the entity and the amount of its cash and cash equivalents and allow for the evaluation of relationships among those activities. The mean compliance for PAS 7 and Section 7 is almost equal to 1 . For the periods 2007-2009, one company failed to classify its statement of cash flow by operating, investing and financing activities. In addition, the other one company failed to report separately major classes of gross receipts and gross cash payments arising from investing and financing activities; interest and dividends and taxes on income. On the other hand, for periods 2010-2012, one company failed to present interest and dividends separately and consistently classify each from period to period for two consecutive years.

\section{Table 6}

Paired T-test: Section 17 vs. PAS 16 or Property, Plant and Equipment

\begin{tabular}{|c|c|c|c|c|c|c|}
\hline Variable & obs & Mean & Std, Enr. & Std, Dev, & {$[95 \%$ conf } & terval]. \\
\hline $\sec 17 \pi n n$ & 21 & .97959918 & .0204082 & 0935219 & .9370212 & 1,022163 \\
\hline pas16minn & 21 & .9312169 & .0294234 & .134835 & .8698408 & 99259331 \\
\hline diff & 21 & .0483749 & .0272458 & 1248558. & -0.084588 & 1052086 \\
\hline
\end{tabular}

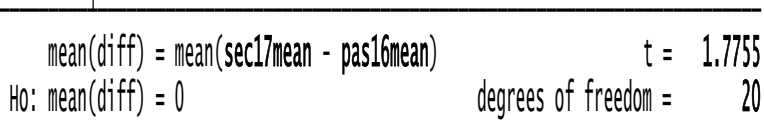

$$
\begin{array}{lcl}
\text { Ha: mean (diff) }<0 & \text { Ha: mean(diff }) !=0 & \text { Ha. mean(diff })>0 \\
\operatorname{Pr}(T<t)=0.9545 & \operatorname{Pr}(|T|>|t|)=0.0910 & \operatorname{Pr}(T>t)=0.0455
\end{array}
$$

Table 6presents the paired t-test results with regard to the companies' compliance with the required disclosures in the Property, Plant and Equipment. It can be seen that during the implementation of full PFRS, companies had an average disclosure of 0.93 , while during the implementation of PFRS for SMEs; companies had an average disclosure of 0.98. This resulted to a positive mean difference of 0.05 , which implies that companies in real estate activities sector become more compliant with the provision of the said standard. At $95 \%$ level of interval, to be significant, $\mathrm{p}$-value should be less than 0.05 . The generated $\mathrm{p}$-value is 0.0910 , therefore, it can be concluded that there is no significant difference in the degree of compliance between Section 17 and PAS 16 despite of the increase in disclosure index.

Among the required disclosures of PAS 16 of the full PFRS and Section 17 of PFRS for SMEs, non-compliance was consistent among the three companies with regard to presenting the gross carrying amount, and the accumulated depreciation at the beginning and end of the period and failed to disclose a reconciliation of the carrying amount of PPE at the beginning and end of the period including the additions and disposals. The importance of disclosing these provisions is explained in the PAS 16, which states that:

"Selection of the depreciation method and estimation of the useful life of assets are matters of judgement. Therefore, disclosure of the methods adopted and the estimated useful lives or depreciation rates provides users of financial statements with information that allows them to review the policies selected by management and enables comparisons to be made with other entities."
Table 7

Paired T-test: Section 23 vs. PAS 18 or Revenue

\begin{tabular}{r|rrrrrr}
\hline Variable & obs & Mean & Std. Err. & Std. Dev. & [95\% Conf. Interval] \\
\hline sec23m n & 30 & .9666667 & .0333333 & .1825742 & .8984923 & 1.034841 \\
pas18m n & 30 & .8814815 & .0447097 & .2448852 & .7900398 & .9729231 \\
\hline diff & 30 & .0851852 & .0329192 & .1803061 & .0178578 & .1525126 \\
\hline
\end{tabular}

mean $($ diff $)=$ mean $(\sec 23$ mean - pas18mean $)$

Ho: $\operatorname{mean}($ diff $)=0$ $t=2.5877$

Ha: mean(diff) $<0$ $\operatorname{Pr}(T<t)=0.9925$

Ha: mean(diff) $!=0$
$\operatorname{Pr}(|T|>|t|)=0,0149$

Ha: mean(diff) $>0$ $\operatorname{Pr}(T>t)=0.0075$

Table 7 shows the paired t-test results with regard to the companies' compliance with the required disclosures in the Revenue. During the implementation of full PFRS, companies had an average of 0.88 while an average of 0.97 during the implementation of PFRS for SMEs. This resulted to a positive mean difference of 0.09 , which implies that companies become more compliant with the provision of this standard. Having a p-value of 0.0149 , it can be concluded that there is a significant difference in the degree of compliance between Section 23 and PAS 18. Common non-compliance with the provision of these standards is about on the disclosure of the accounting policies adopted for the recognition of revenue

Table 8

Paired T-test: Section 32 vs. PAS 10 or Events After

\begin{tabular}{|c|c|c|c|c|c|c|}
\hline variable & obs & Mean & Std. Err. & Std. Dev. & {$[95 \%$ conf } & Interval] \\
\hline $\begin{array}{l}\sec 32 m \sim n \\
\operatorname{pas} 10 m \sim n\end{array}$ & $\begin{array}{l}30 \\
30\end{array}$ & $\begin{array}{l}.9666667 \\
.4722222\end{array}$ & & $\begin{array}{l}.1825742 \\
.1961474\end{array}$ & $\begin{array}{l}.8984923 \\
.3989796\end{array}$ & $\begin{array}{l}1.034841 \\
.5454649\end{array}$ \\
\hline $\operatorname{diff}$ & 30 & .4944444 & .0361663 & 1980911 & .420476 & .568412 \\
\hline \multicolumn{4}{|c|}{ mean $($ diff $)=$ mean $(\sec 32$ mean - pas10mean } & \multicolumn{3}{|c|}{$t=13.6714$} \\
\hline \multicolumn{2}{|c|}{$\begin{array}{l}\text { Ha: } \operatorname{mean}(\text { diff })<0 \\
\operatorname{Pr}(T<t)=1.0000\end{array}$} & \multicolumn{3}{|c|}{$\begin{array}{l}\text { Ha: mean(diff) } !=0 \\
\operatorname{Pr}(|T|>|t|)=0.0000\end{array}$} & \multicolumn{2}{|c|}{$\begin{array}{l}\text { Ha: mean(diff) }>0 \\
\operatorname{Pr}(T>t)=0.0000\end{array}$} \\
\hline
\end{tabular}
The End of the Reporting Period

Table 13 shows the paired t-test results with regard to the companies' compliance with the required disclosures of the standard on events after the end of the reporting period. During the implementation of full PFRS, companies had an average disclosure of 0.47 while an average disclosure of 0.97 during the implementation of PFRS for SMEs. This resulted to a positive mean difference of 0.49 , which implies that companies become more compliant with the provision of this standard. The common error during the implementation of full PFRS was no disclosure if the entity's owners or others have the power to amend the financial statements after issuance. Given p-values, which are less than 0.05 at $95 \%$ 
level of confidence, it can be concluded that there is a significant difference in the degree of compliance between Section 32 and PAS 10.

The most common disclosure requirement not complied with in PAS 10 of full PFRS and Section 32 of PFRS for SMEs, is the disclosure of the date when the financial statements were authorized for issue and who gave that authorization and the disclosure of the power of the entity's owners or others to amend the financial statements after issuance.

Table 9

Paired T-test: Section 33 vs. PAS 24 or Related Party Transactions

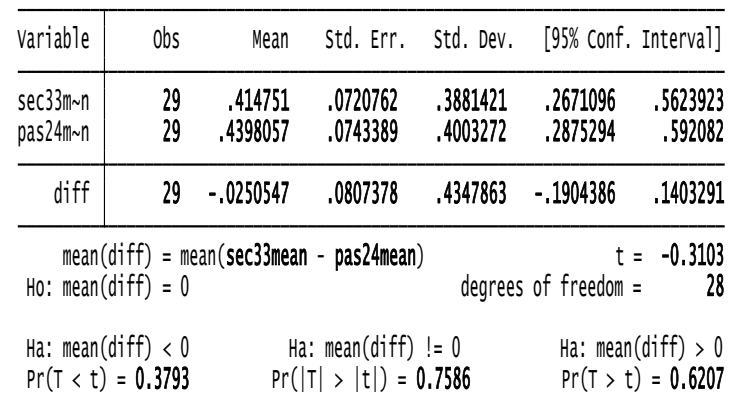

Table 14 presents the paired t-test results with regard to the companies' compliance with the required disclosures of Related Party Transactions. During the implementation of full PFRS, companies had an average disclosure of 0.44 while an average disclosure of 0.41 during the implementation of PFRS for SMEs. The negative mean difference of -0.03 implies that there was a decrease in the compliance for Related Party Transaction disclosures after the implementation of PFRS for SMEs. At 95\% level of confidence, it can be concluded that there is no significant difference in the degree of compliance between Section 33

The most common disclosure requirement not complied with in PAS 24 of full PFRS and Section 33 of PFRS for SMEs, is the disclosure of the key management personnel compensation in total and in the following categories: short-term employee benefits; post-employment benefits; other long-term benefits; termination benefits and share-based payment.

\section{Profitability Ratio}

To certify if there is a significant change in the firm performance, measured by the profitability ratio particularly Return on Assets and Return on Equity, between the use of the full PFRS and the PFRS for SMEs, an evaluation of the trend analysis for each ratio is first examined by the line graphs presented below. The ratios reflected on the trend analysis have been computed by utilizing the balances of the accounts presented on the financial statements particularly on the Statement of Financial Position and Income Statement of the sample companies. Return on Equity measures the firm's ability to generate profits from its shareholders investment in the company. In addition, it also measures how efficiently a firm can use the money from shareholders to generate profits. It can be seen in Figure _, that there were negative returns on 2008 and 2011, this is because some companies incurred and PAS 24.

losses. Overall, Return on Equity is fluctuating.

\section{Return on Assets}

Return on Asset measures the firm's ability to manage its assets efficiently in order to generate profits. Return on assets displays a decreasing trend from 2007 to 2010 due to some companies who incurred losses. Thus, it generated a negative Return on Assets. However, it has an increasing trend from 2010 to 2012 .

\section{Paired T-test on Profitability Ratios}

Apart from the trend analysis, the paired t-test is conducted to determine if there is a significant change between the Profitability ratios before and after the adoption of the PFRS for SMEs.

Table 10

Paired T-test on Return on Equity Ratio

\begin{tabular}{|c|c|c|c|c|c|c|}
\hline Variable & obs & Mean & Std. Err. & Std. Dev. & {$[95 \%$ conf. } & Interval \\
\hline smesroe & 29 & .0481733 & & .4695538 & & .22678 \\
\hline fullroe & 29 & .0233302 & .0981121 & .52835 & -.1776434 & .22430 \\
\hline diff & 29 & .0248431 & 1364949 & .7350478 & -.2547541 & .3044 \\
\hline \multicolumn{4}{|c|}{ mean(diff) = mean(smesroe - fullroe) } & \multicolumn{3}{|c|}{$\begin{aligned} t & =0.1820 \\
\text { dearees of freedom } & =28\end{aligned}$} \\
\hline ta: me & & & & & & \\
\hline $\operatorname{Pr}(T<t$ & & & $T|>| t \mid)=$ & 1.8569 & $\operatorname{Pr}(T$ & -0 \\
\hline
\end{tabular}

Table 15 shows the paired t-test results comparing the Return on Equity before and after the implementation of PFRS for SMEs. It can be seen that Return on Equity using PFRS for SMEs increases as supported by the higher mean value resulting to a positive mean difference of 0.02 . However, despite of its improvement, it is statistically insignificant based on the generated p-value of 0.8569 at $95 \%$ level of confidence.

Table 11

Paired T-test on Return on Assets Ratio

\begin{tabular}{|c|c|c|c|c|c|c|}
\hline variable & obs & Mean & Std. Err. & Std. Dev. & \multicolumn{2}{|c|}{ [95\% Conf. Interval] } \\
\hline $\begin{array}{l}\text { smesroa } \\
\text { fullroa }\end{array}$ & $\begin{array}{l}30 \\
30\end{array}$ & $\begin{array}{r}-.0240987 \\
.0648313\end{array}$ & $\begin{array}{l}.0811729 \\
.0359519\end{array}$ & $\begin{array}{l}.4446021 \\
.1969164\end{array}$ & $\begin{array}{l}-.1901159 \\
-.0086985\end{array}$ & $\begin{array}{l}.1419184 \\
.1383611\end{array}$ \\
\hline diff & 30 & -.08893 & .0616024 & .3374102 & -.2149211 & .037061 \\
\hline \multicolumn{4}{|c|}{$\begin{aligned} \text { mean }(\text { diff }) & =\text { mean }(\text { smesroa }- \text { fullroa }) \\
\text { Ho: } \operatorname{mean}(\text { diff }) & =0\end{aligned}$} & \multicolumn{3}{|c|}{$\begin{aligned} t & =-1.4436 \\
\text { degrees of freedom } & =\quad 29\end{aligned}$} \\
\hline $\begin{array}{l}\text { Ha: mean } \\
\operatorname{Pr}(T<t\end{array}$ & $\begin{aligned}<0 \\
0798\end{aligned}$ & & $\begin{array}{l}\operatorname{mean}(\operatorname{diff} \\
>|\mathrm{t}|)=\end{array}$ & $\begin{array}{l}!=0 \\
1596\end{array}$ & $\begin{array}{l}\text { Ha: mea } \\
\operatorname{Pr}(\mathrm{T}>\end{array}$ & $\begin{array}{l}\text { (diff) }>0 \\
=0.9202\end{array}$ \\
\hline
\end{tabular}

Table 16 shows the paired t-test results comparing the Return on Assets before and after the implementation of PFRS for SMEs. It can be seen that Return on Assets is higher during the implementation of full PFRS, thus it resulted to a mean difference of -0.09 . Generating a p-value of 0.1596 , at $95 \%$ level of confidence, it can be concluded 


\section{IMPACT OF FULL IFRS, ACCOUNTING STANDARS FOR SMES AND COMPANY DEMOGRAPHICS ON FIRMS' RETURN ON ASSET AND RETURN ON EQUITY USING PANEL DATA REGRESSIO}

that there is insignificant difference between the use of full PFRS and PFRS for SMEs.

Disclosure Index vs. Financial Ratios Panel Regression

\section{Firm Characteristics}

To determine whether there is a significant relationship between firm characteristics such as firm age and firm size (measured by years of existence and total asset respectively), and profitability ratio, the Pearson-Product-Moment Correlation test was employed. Results of the said test presents the correlation coefficient, which measures the strength of the linear association between firm characteristics and financial ratios, and the $\mathrm{p}$-value, which measures if there is a significant or not significant relationship between firm characteristics and firm performance. The correlation coefficient ranges between 1 and -1 . If the coefficient is greater than 0 , a positive correlation exists. If the value is equal to 0 , there is no correlation. $f$ the coefficient is less than 0 , a negative correlation exists. In addition, coefficients closer to 1 or -1 indicate a strong positive or negative correlation between the variables. However, it must be note that the Pearson-Product-Moment correlation test can only tell about the strength and the direction of the relationship between dependent variable and independent variable. It cannot specifically tell about the cause-and-effect relationship between the two variables.

Table 12

Correlation between Firm Characteristics and Return on Equity

\begin{tabular}{|l|l|l|}
\hline $\begin{array}{l}\text { Return on } \\
\text { Equity }\end{array}$ & $\begin{array}{l}\text { Correlation } \\
\text { Coefficient }\end{array}$ & $\begin{array}{l}\text { P-value } \\
\text { Interpretation }\end{array}$ \\
\hline Firm Age & $\begin{array}{l}0.0051 \\
\text { Weak Positive }\end{array}$ & $\begin{array}{l}0.9458 \\
\text { Insignificant }\end{array}$ \\
\hline Firm Size & $\begin{array}{l}-0.0074 \\
\text { Weak negative }\end{array}$ & $\begin{array}{l}0.9263 \\
\text { Insignificant }\end{array}$ \\
\hline
\end{tabular}

Table 13

Correlation between Firm Characteristics and Return on Asset

\begin{tabular}{|l|l|l|}
\hline $\begin{array}{l}\text { Return } \\
\text { on } \\
\text { Asset }\end{array}$ & $\begin{array}{l}\text { Correlation } \\
\text { Coefficient }\end{array}$ & $\begin{array}{l}\text { P-value } \\
\text { Interpretation }\end{array}$ \\
\hline $\begin{array}{l}\text { Firm } \\
\text { Age }\end{array}$ & $\begin{array}{l}0.2014 \\
\text { Weak Positive }\end{array}$ & $\begin{array}{l}0.0058 \\
\text { Significant }\end{array}$ \\
\hline Firm & -0.1278 & 0.1073 \\
Size & Weak negative & Insignificant \\
\hline
\end{tabular}

Table 13 shows the correlation between firm characteristics (firm age and firm size) and profitability ratios of the sample companies in real estate activities sector. Based on the results, firm age shows a weak positive correlation to Return on Equity and Return on Assets. This weak positive correlation implies that as the value of one variable increases; the value of the other variable also increases. Overall, the weak positive correlation between firm age and Return on Assets is significant. This correlation may imply indirectly that as the firms grow older, the Return on Assets is improving. It will have a positive impact on the investors as it shows that through the years, companies are able to manage their assets effectively in order to generate net income. With regard to firm size, it shows a weak negative correlation to both Return on Equity and Return on Asset.

\section{CONCLUSION}

The results show that the adoption of PFRS for SMEs improved the compliance of Philippine real estate SMEs. However, no significant change was noted in the financial performance of these firms (as measured by return on assets and return on equity). This was further supported by the results of the panel regression. This means that despite having a relatively easier time in complying with the required accounting standards, this did not translate to having lower significantly costs related to compliance. It was also noted that firm characteristics, namely, firm age and firm size, are generally not correlated with the firm's profitability.

During the implementation of full PFRS, companies had an average of 0.97 while a disclosure index of 1 during the implementation of PFRS for SMEs. This resulted to a positive mean difference of 0.03 , which implies that companies become more compliant with the provision of this standard. Having a p-value of 0.2122 at $95 \%$ confidence level, it can be concluded that there is no significant difference in the degree of compliance between Section 29 and PAS 12. For periods 2007-2009, common noncompliance was the separate disclosure of the major components of current tax expense.

This weak positive correlation implies that as the value of one variable increases; the value of the other variable also increases. Overall, the weak positive correlation between firm age and Return on Assets is significant. This correlation may imply indirectly that as the firms grow older, the Return on Assets is improving. It will have a positive impact on the investors as it shows that through the years, companies are able to manage their assets effectively in order to generate net income. With regard to firm size, it shows a weak negative correlation to both Return on Equity and Return on Asset.

\section{REFERENCES}

1. Abarca, J.A. (February 10, 2014). One economic region, one accounting framework. Business World. Retrieved last July 24, 2016 from SGV website, http://www.sgv.ph/one-economic-region-one-accountingframework-byjosephineadrienne-a-abarca-february-10-20 $14 / 2$

2. Aldaba, R.M. (2012). Small and Medium Enterprises' (SMEs) Access to Finance: Philippines. Retrieved last July 7, 2016 from Philippine Institute for Development Studies website: http://dirp4.pids.gov.ph/ris/dps/pidsdps1205.pdf

3. Bohusova, H., \& Blaskova, V. (2011). In what ways are countries which have already adopted IFRS for SMEs different. Retrieved last July 25, 2016 from http://acta.mendelu.cz/media/pdf/actaun_2012060020037 .pdf

4. Chyzhevska, L., Müllerov., L., Paseková, M., \& Strouhal, J. (2010). IFRS for SMEs: Challenge for emerging countries? Case of Czech Republic and Ukraine. World Academy of Science, Engineering and Technology, 66, 1691-1694. 
5. Department of Trade and Industry. (2014). MSME Statistics. Retrieved last July 8, 2016 from DTI website: http://www.dti.gov.ph/dti/index.php/resources/sme-resou rces/sme-statistics

6. Dogan, M. (2013). Does Firm Size Affect the Firm Profitability? Evidence from

7. Turkey. Retrieved last July 24, 2016 from http://www.iiste.org/Journals/index.php/RJFA/article/vie w/4977/5060

8. Dulay, D. (February 3, 2014). 7.2\% GDP growth: Gaming the numbers? The Manila Times. Retrieved last July 7 , 2016 from The Manila Times website http://www.manilatimes.net/7-2-gdp-growth-gaming-thenumbers/73024/

9. Epstein, B., \& Jermakowicz, E. (2009). IFRS Converges to U.S. GAAP on segment reporting. Journal of Accountancy. Retrieved from Journal of Accountancy website,http://www.journalofaccountancy.com/Issues/20 09/Apr/20081008.htm

10. Masca, E., Neag, R., \& Pascan, I. (2009). Actual aspects regarding the IFRS for SME- opinions, debates and future developments. Retrieved last July 17, 2016 from http://www.oeconomica.uab.ro/upload/lucrari/1120091/0 3.pdf

11. Mullerova, L., Pasekova, M., \& Kubickova, D. (2010). Analysis of differences in reporting according to IFRS for SMEs in the Czech Republic and its influence on performance measurement. Retrieved last July 17, 2016 from https://is.vsfs.cz/repo/2527/1.clanek.pdf

12. National Statistical Coordination Board. (2009) Philippine Standard Industrial Classification. Retrieved last July $7, \quad 2016 \quad$ from http://nap.psa.gov.ph/activestats/psic/publication/NSCB PSIC_2009.pdf

13. Pacter, P. (2009). An IFRS for private entities. Retreived last July $17, \quad 2016 \quad$ from http://www.fee.be/images/publications/sme-smp/Pacter1 09200816157.pdf

14. Palka P., \& Svitakova S. (2011). "Impact of IFRS for SMEs adoption on performance of Czech Companies". Retrieved last July 24, 2016 from http://www.wseas.us/e-library/conferences/2011/Angers/ EMT/EMT-07.pdf

15. Pervan, M., \& Visic, J. (2012). Influence of firm size on its business success. Croatian Operational Research Review, 3. Retrieved last July 24, 2016 from www.hrcak.srce.hr/file/142467

16. Philippine Statistics Authority. (May 30, 2016). 2013 Annual Survey of Philippine Business and Industry (ASPBI) - Real Estate Activities: Final Results. Retrieved last July 7, 2016 from PSA website: https://psa.gov.ph/content/2013-annual-survey-philippine -business-and-industry-aspbi-real-estate-activities-final

17. Raju, K. S. (n.d). Benefits of adopting IFRS for SMEs. Retrieved last July 17, 2016 from http://www.taxmann.com/taxxmanflashes/flashart9-2-10 5.htm

18. Schutte, D., and Buys, P. (2011). A Comparative evaluation of South African SME financial statements against the IFRS requirements. Retrieved last July 24, 2016

from http://www.academicjournals.org/article/article13794039 28_Schutte\%20and\%20Buys.pdf

19. Stokdyk, J. (2010, March 6). EU uncovers resistance to IFRS for SMEs. Retrieved July 24, 2016, from http://www.accountingweb.co.uk/topic/financial-reportin g/eu-uncovers-resistanceifrs-smes/429509

20. Strouhal, J., Pasekova, M., and Mullerova, L. (2010). Comparative Analysis of Czech Accounting with
International Regulation for SMEs Perspective. Retrieved last July 25, $2016 \quad$ from http://www.vse.cz/polek/download.php?jnl=efaj\&pdf=38 .pdf

21. Symeou, P. (2010). The effects of economy size on firm performance: evidence from the telecommunication sector. Retrieved July 24, 2016, from http://papers.ssrn.com/so13/papers.cfm?abstract_id=1465 356

22. Veronica, G., \& Ionel, B. (2010). IAS/IFRS standards for SMEs and the impact on the Romanian accounting system. International Journal of Academic Research, 2(4): 323-328.

23. Yason, S.V. (November 10, 2014). Financial Reporting: A Challenge to SMEs. Retrieve last July 7, 2016 from SGV website: http://www.sgv.ph/financial-reporting-a-challenge-to-sm es-by-sherwin-v-yason-november-10-2014/ 